Morris, T. et al. (2013). No association between cumulative traumatic experiences and sex in risk for posttraumatic stress disorder among human immunod eficiency virus-positive adults.

\title{
No association between cumulative traumatic experiences and sex in risk for posttraumatic stress disorder among human immunodeficiency virus-positive adults
}

Tanya Morris, Pamela Naidoo, Karen J. Cloete, Justin Harvey, and Soraya Seedat

\begin{abstract}
This study examined the association between the type and number of traumatic experiences and the conditional risk for posttraumatic stress disorder (PTSD), stratified by sex, in human immunodeficiency virus (HIV). We evaluated 465 (114 male and 350 female) HIV-positive adults attending HIV clinics in Cape Town, South Africa. Demographic and clinical data were collected, and the participants were screened for current PTSD and traumatic event exposure using the Mini-International Neuropsychiatric Interview and the Life Events Checklist, respectively. The highest attributable risk for PTSD was derived from sexual assault (17.4\%) and transport accidents (16.9\%). Only sexual assault was significantly $(p=0.002)$ associated with current PTSD. Although sex had no effect on the prediction of current PTSD, HIVinfected men tended to experience more lifetime traumas than HIV-infected women, with the men having significantly higher rates of exposure than women to physical assault ( $p=$ o.018) and assault with a weapon $(p=0.001)$. These data highlight the importance of considering trauma type in contributing to the burden of PTSD in HIV-infected adults.
\end{abstract}

Estimates from the World Mental Health Survey suggest that the burden of mental illness such as depression, posttraumatic stress disorder (PTSD), and substance abuse may be substantial in those living with human immunodeficiency virus (HIV) and acquired immunodeficiency syndrome (AIDS) (Demyttenaere et al., 2004). Of these, PTSD is one of the most prevalent mental disorders, with rates ranging from $10.4 \%$ to $42 \%$ in people living with HIV/AIDS (Kelly et al., 1998; Martinez et al., 2002; Pingo and Seedat, 2009; Radcliffe et al., 2007). In developing countries such as South Africa, both PTSD and trauma exposure are common concomitants of HIV/AIDS (Olley et al., 2005).

PTSD may develop secondary to a diagnosis of HIV/AIDS (Olley et al., 2005, 2006) or after other traumas in infected patients, in particular, interpersonal traumas (Mar tin and Kagee, 2011; Olley et al., 2005, 2006; Radcliffe et al., 2007). In a study undertaken on the prevalence of and factors associated with PTSD in patients with recently diagnosed HIV in South Africa (Cape Town), major depression and PTSD were the most common disorders at both baseline (35\% and 15\%, respectively) and follow-up (26\% and $20 \%$, respectively; Olley et al., 2005, 2006). Female sex was significantly associated with the 
development of PTSD, with PTSD appearing secondary to both a diagnosis of HIV/AIDS and a range of other lifetime traumas in $14.8 \%$ of patients (Olley et al., 2005).

Traumatic life events are highly prevalent in HIV-infected adults (Martinez et al., 2002; Pingo and Seedat, 2009). For example, prevalence rates for child and adult sexual abuse among HIV-infected individuals are in the order of $32 \%$ to $68 \%$. Furthermore, a significant association has been documented between the number and severity of traumatic exposures and PTSD (Olley et al., 2005). In fact, HIV-positive individuals exposed to multiple traumatic life events are more likely to develop PTSD (Kimerling et al., 1999; Olley et al., 2005). However, even in those individuals exposed to very severe traumatic events, only a small proportion develops PTSD (Voges and Romney, 2003).

Sexual assault has been found to be the strongest predictor of PTSD (Olley et al., 2005), whereas physical assault also carries a high conditional risk for PTSD (Kaminer et al., 2008). Within a representative South African general population sample, violence was, however, shown to be more likely associated with PTSD than other forms of trauma (Kaminer et al., 2008). Besides previous traumatic events and/or inherent stressors, being diagnosed with HIV could also potentially be a significant traumatic stressor because many HIV-infected individuals are marginalized in some way before receipt of the diagnosis (Safren et al., 2003). Concerns about the future and factors relating to disease course could also bring about additional stress and trauma (Martin and Kagee, 2011).

There is currently limited data on HIV-related PTSD in the context of trauma load and sex differences (Radcliffe et al., 2007) as well as on the risk after both assaultive and nonassaultive traumas, particularly in a developing country setting. This study therefore sought to examine the association between the number and type of traumatic experiences and the conditional risk for PTSD in HIV-infected patients. The objectives of this study were to examine a) the association between cumulative trauma and PTSD risk in HIV-infected adults; b) the conditional risk for PTSD based on trauma type; and c) the association of trauma type and load, by sex, with respect to PTSD. The primary hypothesis of this study, which formed part of a larger study (Myer et al., 2008), was that a higher trauma load and sexual assault (as compared with other nonassaultive traumas) would show the greatest association with PTSD in HIV-infected patients and that this association would be significantly predicted by female sex.

\section{Methods}

\section{Setting and participants}

This was a cross-sectional study undertaken between October 2004 and December 2005 at three HIV clinics in Cape Town, South Africa. All three facilities provide general HIV care and antiretroviral treatment free of charge. Participants $(N=465)$ were patients with confirmed HIV status receiving care at these centers and eligible for this study if they tested positive for HIV according to medical records, were between the ages of 18 and 65 years, had a MiniYMental State Examination (MMSE; Sheehan et al., 1998) score of 24 or greater, and provided written informed consent for questionnaire administration and clinician access to medical records. Individuals were excluded from 
this study if they could not provide written informed consent, were younger than 18 years or older than 65 years, were found to be globally cognitively impaired (as indicated by a cutoff score of less than 24 on the MMSE), or were HIV-positive mothers in the first 6 months postnatally. The Committee for Human Research of the University of Stellenbosch granted ethical approval for this study.

\section{Study Procedures}

Data were collected in two separate interviews carried out during routine clinic visits in private rooms at each facility. During the first interview of approximately 30 minutes, trained interviewers collected demographic data and screened participants for PTSD using screening tools selected on the basis of their ease of administration and existing evidence for cross-cultural administration. The questionnaires were translated into Afrikaans and Xhosa for the non-English speaking participants. To prevent bias from influencing the clinical diagnosis, researchers were blinded to all data obtained during the preliminary interview. After completion of both interviews, the clinic staff extracted clinical and immunological data (CD4 count, viral load, and antiretroviral treatment status) from chart records.

To identify the number and type of events that would qualify as traumatic or life threatening, including vicarious trauma, as defined by the Diagnostic and Statistical Manual of Mental Disorders, Fourth Edition, Text Revision (DSM-IV-TR; American Psychiatric Association, 2000), we used the Life Events Checklist (LEC; Gray et al., 2004). The LEC is a brief, 17-item, self-report measure designed to screen for potentially traumatic events in an individual's lifetime. The LEC assesses exposure to 16 events known to potentially result in PTSD or distress and includes one item assessing any other extraordinarily stressful event not captured in the first 16 items. For each item, the respondent checks whether a) the events happened to them personally, b) they witnessed the event, (c) they learned about the event, (d) they are not sure whether the item applies to them, and (e) the item does not apply to them. The LEC has demonstrated adequate psychometric properties as a stand-alone assessment of traumatic exposure, particularly when evaluating consistency of events that an individual has directly experienced. The LEC has also demonstrated convergent validity with measures assessing varying levels of exposure to potentially traumatic events and psychopathology known to relate to traumatic exposure (Gray et al., 2004). Traumatic events were defined as natural disaster, fire/explosion, transport accident, serious accident at home/work/sports, physical assault, assault with a weapon, sexual assault, other unwanted/uncomfortable sexual experience, exposure to trauma in a war zone (soldier/civilian), captivity (kidnapped/abducted/hostage), life-threatening illness/injury, exposure to sudden/violent death (murder/suicide), sudden/unexpected death of someone close, and serious injury/harm/death the participant caused to someone. A cumulative trauma score was calculated on the basis of the number of different traumas on the LEC, with each trauma assigned a score of 1 point.

The Mini-International Neuropsychiatric Interview (MINI) was used as the criterion standard structured diagnostic clinical interview for the assessment of current PTSD (Sheehan et al., 1998). The MINI has been validated against the Structured Clinical Interview for DSM-III (American Psychiatric Association, 1980) and has been used as a 
criterion standard for diagnostic screening in HIV studies in South Africa (Myer et al., 2008; Olley et al., 2003, 2005). For more detail on the study methods, see study by Myer et al. (2008).

\section{Analyses}

Secondary data analysis was conducted using the Statistical Package for the Social Sciences, version 17.0. Bivariate analyses using the chi-square test and Mann-Whitney's $U$-test were performed to examine crude (unadjusted) associations between demographic and clinical variables and PTSD. Subsequently, multivariate logistic regression analyses were used to determine the association between type of trauma, cumulative trauma, and conditional risk for PTSD; trauma type and number of trauma exposures stratified, by sex, with respect to PTSD; and c) sex differences in PTSD. Variables (independent: demographic, sex, type of and cumulative trauma, HIV disease status; dependent: PTSD) were entered in the multivariate model if these demonstrated an appreciable association in the bivariate analyses and were retained if their association with PTSD outcome persisted after univariate statistical adjustments or if their removal altered associations involving other covariates. In the model, we adjusted for comorbid psychiatric disorders. Model checking and diagnostics followed standard procedures (Hosmer and Lemeshow, 1989). The conditional probability of PTSD was estimated on the basis of those traumas that were found to be significant in the univariate/bivariate analyses. The results of logistic regression modeling are expressed as unadjusted odds ratios (ORs) with 95\% confidence intervals for each traumatic event. All statistical tests were two sided at $>=0.05$.

\section{Results}

Data were included from a total of 465 participants. Their demographic data are listed in Table 1. The mean (SD) age of the participants was 34 (8.00) years, with most participants in the age category $24 \mathrm{Y} 40$ years. The sample was predominantly female $(n=$ $350,75.27 \%)$ and black $(n=332,71.40 \%)$ most participants had completed grade 8 to $12(n=380,81.72 \%)$, and approximately a third $(n=162,34.84 \%)$ was unemployed. The mean (SD) CD4 count was $273(194)$, and $52 \%(n=256)$ of participants were on antiretroviral treatment. The three most common types of trauma endorsed were sudden/unexpected death of someone close $(n=200,43.01 \%)$, life-threatening illness/injury ( $n=184,39.57 \%)$, and physical assault $(n=170,36.56 \%)$. A quarter $(n=$ 8o, 17.41\%) of the sample experienced sexual assault, whereas $8.60 \%(n=40)$ were exposed to trauma in a war zone (combat/civilian). Twenty-four participants (5\%) met the criteria for a DSM-IV-TRYdefined diagnosis of PTSD. 


\begin{tabular}{|c|c|c|}
\hline & $n$ & $\%$ \\
\hline \multicolumn{3}{|l|}{ Sex } \\
\hline Male & 114 & 24.52 \\
\hline Female & 350 & 75.27 \\
\hline \multicolumn{3}{|l|}{ Language } \\
\hline Xhosa & 309 & 66.4 \\
\hline Afrikaans & 118 & 25.38 \\
\hline English/other & 38 & 8.17 \\
\hline \multicolumn{3}{|l|}{ Race } \\
\hline Black & 332 & 71.40 \\
\hline Colored & 120 & 25.81 \\
\hline Asian/white/other & 13 & 2.80 \\
\hline \multicolumn{3}{|l|}{ Sexuality } \\
\hline Heterosexual & 435 & 93.5 \\
\hline Homosexual & 12 & 2.5 \\
\hline Bisexual & 4 & 0.86 \\
\hline \multicolumn{3}{|l|}{ Marital status } \\
\hline Married/in a relationship & 308 & 66.52 \\
\hline Single/divorced/widowed & 155 & 33.48 \\
\hline \multicolumn{3}{|l|}{ Education } \\
\hline Grade 1-7 & 63 & 13.5 \\
\hline Grade $8-12$ & 380 & 81.72 \\
\hline Tertiary diploma/degree & 6 & $1.2 \mathrm{~S}$ \\
\hline \multicolumn{3}{|l|}{ Employment status } \\
\hline Working & 119 & 25.5 \\
\hline Disabled & 136 & 29.25 \\
\hline Pensioner & 15 & 3.23 \\
\hline Unemployed & 162 & 34.8 \\
\hline Other (casual employment) & 21 & 4.52 \\
\hline
\end{tabular}

Only language ( $p$ G 0.01) and marital status ( $p=0.03$ ) were significantly associated with a diagnosis of PTSD. None of the clinical variables were significantly associated with a diagnosis of PTSD.

With regard to trauma type, only sexual assault was significantly $(p=0.002)$ associated with a diagnosis of PTSD. Being involved in a transport accident showed a trend toward significance $(p=0.078$ ) with PTSD (Table 2). No significant association was found between trauma load (total number of traumas participants were exposed to) and PTSD.

Notably, the participants exposed to lifetime sexual assault had four times greater odds (OR, 4.09) of being diagnosed with PTSD than those who were not exposed to sexual assault (Table 2), whereas those involved in a transport accident had twice the odds (OR, 2.19) of being diagnosed with PTSD (Table 2).

Of the 24 participants who met criteria for PTSD, the majority ( $n=19,79 \%)$ was female. Men had significantly higher rates of exposure to physical assault $(n=51$, $44.74 \%, p=0.018)$ and assault with a weapon $(n=51,44.74 \%, p=0.001)$ than did the women (physical assault $[n=118,33.71 \%]$ and assault with a weapon $[n=104$, 29.71\%]; Table 3). In contrast, the women $(n=68,19.43 \%)$ were significantly ( $p=0.031)$ more likely to be exposed to sexual assault than were men $(n=13,11.40 \%$; Table 3$)$. 
For number of lifetime traumatic exposures, the results indicated that there was a trend toward significance ( $p=0.196$ ), with the men (mean T SD, 5.53 T 3.58) endorsing more lifetime traumas than women (mean T SD, $4.94 \mathrm{~T} 3.21$ ).

\section{Discussion}

The results of this study identify and highlight the significant contribution of specific trauma types to PTSD among HIV-infected individuals, in particular, sexual assault and transport accidents, and the sex differential with regard to traumatic event exposures. Notably, we found no significant relationship between trauma load (characterized by the number of different traumatic exposures) and PTSD in our HIV sample. In contrast, other studies have found a significant association between trauma load and PTSD in HIVpositive individuals (Martinez et al., 2002; Olley et al., 2005).

\begin{tabular}{|c|c|c|c|c|c|c|c|c|}
\hline & \multirow[b]{2}{*}{$\begin{array}{c}\text { Total } \\
\text { Sample, } n(\%)^{\mathrm{a}}\end{array}$} & \multicolumn{2}{|c|}{ PTSD, $n(\%)^{\mathrm{b}}$} & \multirow[b]{2}{*}{$\chi^{2}$ Statistic $^{c}$} & \multirow[b]{2}{*}{$p^{*}$} & \multirow[b]{2}{*}{$\begin{array}{c}\text { Univariate } \\
\text { Analysis, }^{\mathrm{d}}{ }^{-} \\
\text {OR }(95 \% \mathrm{CI}) \\
\end{array}$} & \multirow[b]{2}{*}{$\begin{array}{c}\text { Multivariate } \\
\text { Analysis, }{ }^{\text {e }} \\
\text { OR }(95 \% \text { CI) }\end{array}$} & \multirow{2}{*}{$\begin{array}{c}\text { PTSD } \\
\text { Attributable } \\
\text { Risk to Traumatic } \\
\text { Event }\end{array}$} \\
\hline & & Yes & No & & & & & \\
\hline Natural disaster & 37 (7.96) & $2(8.7)$ & $35(12.6)$ & 0.305 & 0.592 & $0.664(0.15-2.93)$ & & \\
\hline Fire/explosion & $138(29.68)$ & $12(52.2)$ & $125(45.0)$ & 0.445 & 0.496 & $1.345(0.57-3.13)$ & & \\
\hline Transport accident & $130(27.96)$ & $14(60.9)$ & $115(41.7)$ & 3.192 & $0.078^{*}$ & $2.194(0.91-5.20)^{*}$ & $1.680(0.68-4.16)$ & $16.87 \%$ \\
\hline $\begin{array}{l}\text { Serious accident } \\
\text { at home/ } \\
\text { work/sports }\end{array}$ & $112(24.09)$ & $9(39.1)$ & $102(36.7)$ & 0.054 & 0.777 & $1.135(0.46-2.65)$ & & \\
\hline Physical assault & $170(36.56)$ & $13(56.5)$ & $155(55.8)$ & 0.005 & 0.894 & $1.061(0.44-2.43)$ & & \\
\hline $\begin{array}{l}\text { Assaulted with } \\
\text { a weapon }\end{array}$ & $156(33.55)$ & $14(60.9)$ & $140(50.4)$ & 0.939 & 0.285 & $1.621(0.64-3.66)$ & & \\
\hline Sexual assault & $81(17.41)$ & $13(56.5)$ & $67(24.1)$ & 11.442 & $0.002 *$ & $4.091(1.72-9.76)^{*}$ & $3.601(1.47-8.85)$ & $17.41 \%$ \\
\hline $\begin{array}{l}\text { Other unwanted/ } \\
\text { uncomfortable } \\
\text { sexual experience }\end{array}$ & $68(14.62)$ & $4(17.4)$ & $63(22.7)$ & 0.351 & 0.544 & $0.708(0.23-2.18)$ & & \\
\hline $\begin{array}{l}\text { Exposure in war zone } \\
\text { (combat/civilian) }\end{array}$ & $40(8.60)$ & $0(0.0)$ & $40(14.5)$ & 3.864 & 0.952 & $<0.001(<0.001)$ & & \\
\hline $\begin{array}{l}\text { Captivity (kidnapped/ } \\
\text { abducted/hostage) }\end{array}$ & $54(11.61)$ & $3(13.0)$ & $51(18.4)$ & 0.415 & 0.528 & $0.668(0.19-2.32)$ & & \\
\hline $\begin{array}{l}\text { Life-threatening } \\
\text { illness/injury }\end{array}$ & $184(39.57)$ & $16(69.6)$ & $165(59.4)$ & 0.924 & 0.317 & $1.601(0.62-3.93)$ & & \\
\hline $\begin{array}{l}\text { Exposure to sudden/ } \\
\text { violent death } \\
\text { (murder/suicide) }\end{array}$ & $84(18.06)$ & $9(39.1)$ & $75(27.1)$ & 1.531 & 0.221 & $1.731(0.72-4.17)$ & & \\
\hline $\begin{array}{l}\text { Sudden/unexpected } \\
\text { death of someone } \\
\text { close }\end{array}$ & $200(43.01)$ & $16(69.6)$ & $182(65.9)$ & 0.125 & 0.741 & $1.168(0.47-2.97)$ & & \\
\hline $\begin{array}{l}\text { Serious injury/harm/ } \\
\text { death you caused } \\
\text { to someone }\end{array}$ & $68(14.62)$ & $7(30.4)$ & $61(22.0)$ & 0.858 & 0.351 & $1.561(0.61-3.94)$ & & \\
\hline $\begin{array}{l}\mathrm{CI} \text { indicates confidence } \\
{ }^{\mathrm{a}} \text { Percentage of participa } \\
{ }^{\mathrm{b}} \text { Percentages represent } \\
{ }^{\mathrm{c}} d f=1 \text {. } \\
{ }^{\mathrm{d}} \text { Odds ratios for univari } \\
{ }^{\circ} \text { Odds ratios for multiva } \\
{ }^{*} \text { Significant at the } 0.05\end{array}$ & $\begin{array}{l}\text { interval. } \\
\text { nts exposed to DSM- } \\
\text { hose with and withou } \\
\text { ate logistic regression } \\
\text { riate logistic regressic } \\
\text { level. }\end{array}$ & $\begin{array}{l}V \text { qualifying tr } \\
\text { t PTSD who es } \\
\text { controlling fo } \\
\text { on, controlling }\end{array}$ & $\begin{array}{l}\text { raumatic events } \\
\text { endorsed expost } \\
\text { or sex. } \\
\text { for sex. }\end{array}$ & $\begin{array}{l}\text { s determined } \\
\text { to each of the }\end{array}$ & $\begin{array}{l}\text { on the LEC } \\
\text { PTSD qua }\end{array}$ & alifying traumatic events. & & \\
\hline
\end{tabular}




\begin{tabular}{|c|c|c|c|c|c|c|c|}
\hline & \multirow{2}{*}{\multicolumn{2}{|c|}{$\frac{(n=114)^{\mathrm{a}}}{\text { Male }}$}} & \multirow{2}{*}{\multicolumn{2}{|c|}{$\begin{array}{c}(n=350)^{\mathrm{a}} \\
\text { Female }\end{array}$}} & \multirow{3}{*}{$\underset{\text { Statistic }^{b}}{\chi^{2}}$} & \multirow[b]{3}{*}{$p$} & \multirow[b]{3}{*}{ OR $(95 \% \mathrm{CI})^{\mathrm{e}}$} \\
\hline & & & & & & & \\
\hline & $n$ & $\%$ & $n$ & $\%$ & & & \\
\hline Natural disaster & 12 & 10.53 & 25 & 7.14 & 1.270 & 0.260 & $0.654(0.31-1.37)$ \\
\hline Fire/explosion & 34 & 29.82 & 103 & 29.43 & 0.001 & 0.971 & $1.010(0.60-1.70)$ \\
\hline Transport/accident & 37 & 32.46 & 93 & 26.57 & 1.682 & 0.200 & $0.708(0.42-1.19)$ \\
\hline Serious accident: work/home/sports & 32 & 28.07 & 79 & 22.57 & 1.427 & 0.232 & $0.724(0.43-1.23)$ \\
\hline Physical assault & 51 & 44.74 & 118 & 33.71 & 5.604 & $0.018^{*}$ & $0.521(0.30-0.90)$ \\
\hline Assaulted with a weapon & 51 & 44.74 & 104 & 29.71 & 10.741 & $0.001 *$ & $0.408(0.24-0.70)$ \\
\hline Sexual assault & 13 & 11.40 & 68 & 19.43 & 4.637 & $0.031^{*}$ & $2.047(1.06-3.96)$ \\
\hline Other unwanted/uncomfortable sexual experiences & 15 & 13.16 & 53 & 15.14 & 0.404 & 0.530 & $1.232(0.65-2.34)$ \\
\hline Exposure in war zone & 14 & 12.28 & 26 & 7.43 & 2.552 & 0.110 & $0.564(0.28-1.15)$ \\
\hline Captivity & 16 & 14.04 & 38 & 10.86 & 0.751 & 0.390 & $0.750(0.39-1.44)$ \\
\hline Life-threatening illness/injury & 51 & 44.74 & 132 & 37.71 & 2.129 & 0.150 & $0.667(0.39-1.15)$ \\
\hline Exposure to sudden/violent death & 22 & 19.30 & 62 & 17.71 & 0.144 & 0.704 & $0.894(0.50-1.60)$ \\
\hline Sudden, unexpected death of someone close & 48 & 42.11 & 152 & 43.42 & 0.057 & 0.811 & $1.069(0.62-1.85)$ \\
\hline Serious injury/harm/death you caused to someone & 20 & 17.54 & 48 & 13.71 & 1.059 & 0.303 & $0.729(0.40-1.33)$ \\
\hline $\begin{array}{l}\text { CI indicates confidence interval. } \\
{ }^{2} \text { All cases with missing data were excluded. } \\
{ }^{b} d f=1 \text {. } \\
\text { cOdds ratios for univariate logistic regression. } \\
\text { *Significant at the } 0.05 \text { level. }\end{array}$ & & & & & & & \\
\hline
\end{tabular}

Nevertheless, a number of studies in general population (Breslau et al., 1999a; Frans et al., 2005) and in HIV-infected (Adewuya et al., 2009; Leserman et al., 2005) samples have documented that multiple episodes of trauma are a significant risk factor of PTSD. Although our findings did not find a significant association between the number of traumas and PTSD, other unmeasured trauma variables, such as individual trauma severity, trauma duration, and chronicity, as well as repeated exposures to the same trauma, may be confounding this relationship and warrant further inquiry.

Our findings also highlight the significant relationship between specific traumas and PTSD in HIV. The three most common types of trauma endorsed in this study were sudden/unexpected death of someone close, life-threatening illness/injury, and physical assault. The high rates of assaultive types of events and motor vehicle accidents are also fairly consistent with data for this province (Western Cape), which indicate that intimate and assaultive violence are a major contributing factor to mental illness and injury in the Western Cape compared with road traffic accidents, the second major contributing factor (Bradshaw et al., 2004; Myers and Naledi, 2008). Sexual assault was the only trauma significantly associated with a diagnosis of PTSD, whereas transport accidents showed a trend toward significance. In addition, when considering all trauma exposures, we found that sexual assault carried the highest conditional risk for PTSD, followed by transport accidents. It is well documented that rape, sexual abuse, and other personal traumas are associated with a higher risk for PTSD compared with serious accidents (Breslau, 2002; Brewin et al., 2000; Hapke et al., 2006; Olley et al., 2005, 2006). Of the interpersonal traumas, physical and sexual assault have also been found to have the strongest association with PTSD (Acier no et al., 1997; Frans et al., 2005; Kaminer et al., 2008; Olley et al., 2005).

Although more women met the criteria for PTSD compared with men, the sex difference was not significant. Hapke et al. (2006), in a representative epidemiological sample, found that sex did not independently predict PTSD, although the conditional probability of PTSD after exposure to trauma was higher in women (11.1\%) than men $(2.9 \%)$. Other 
studies in HIV (Brief et al., 2004; Olley et al., 2005) and general population (Becker man and Auerbach, 2011; Breslau et al., 1999a; Kessler et al., 1995) samples have shown that female sex carries the highest conditional risk for PTSD, with this effect regardless of other sociodemographic variables, such as race and ethnicity. Although few data are available on sex differences in PTSD in HIV-infected patients, one recent study that investigated sex difference in the manifestations of PTSD in patients attending ongoing HIV/AIDS counseling found that women reported higher levels of emotional distress in response to the memory of their traumatic experience compared with men (Becker man and Auerbach, 2011). There were no other significant sex differences in PTSD symptoms. It is plausible that although the rates of PTSD may be similar between the sexes in this study, there may be phenotypic-level differences that were not explored in the current study and warrant further research.

Men tended to experience more lifetime traumas than women. This has been consistently documented in several other large studies (Breslau et al., 1999b; Hapke et al., 2006; Kessler et al., 1995). Lifetime occurrence of other events involving assaultive violence, accidents, and witnessing violence has been shown to be higher in men than in women, with the converse true for rape and sexual assault other than rape (Breslau, 2002; Kessler et al., 1995). Expectedly, women in the present study had a significantly higher rate of exposure to sexual assault. The submissive position of women within social and economic contexts increases their vulnerability to sexual assault (Israelski et al., 2007). Furthermore, South African women have to cope with various social stressors and roles and are exposed to a high burden of intimate partner violence; this places them in subservient positions and are hence at an increased risk for sexual exploitation (Israelski et al., 2007; Olley et al., 2003). The men, in contrast, had a significantly higher rate of exposure to physical assault and assault with a weapon, and this is consistent with South African epidemiological data (Kaminer et al., 2008). Overall, the abovementioned findings support previous research and show that although men experience more traumas, there are distinctive differences in the type of exposure (Kaminer et al., 2008).

Limitations of this study include a) missing data and the relatively small sample of male participants, which may have impacted on the statistical significance of the findings; b) the lack of assessment of lifetime PTSD (because the MINI assesses for current PTSD only); and c) the lack of inclusion of symptom severity measures for PTSD. In view of the cross-sectional study design, inferences regarding causality cannot be drawn. Furthermore, we counted individual traumas as single occurrences without considering multiple exposures to the same trauma and their association with PTSD. In addition, the analyses did not account for trauma duration, chronicity, or severity. To date, few studies have attempted to screen or control for multiple exposures when evaluating the psychological impact or the relative impact of individual traumatic events (Green et al., 2000). Although these studies reflect the actual distribution of traumatic events, these are limited in their ability to make specific links between exposure types and outcomes.

In conclusion, these data highlight the importance of considering trauma type, in particular, nonassaultive events, in contributing to the burden of PTSD in HIV-infected adults and suggest that, in this population, the risk for PTSD among men may be 
comparable to women. HIV/AIDS, interpersonal violence, and injuries from traffic accidents are among the top five contributors to loss of disability-adjusted life years among South Africans, contributed to by poverty, inequality, and alcohol as well as drug misuse (Nor man et al., 2007; Seedat et al., 2009). Prevention of injuries and violence therefore remains a national health priority. More fine-grained investigations of the nature and meaning of traumatic exposures and a sex analysis of the range of PTS phenomenology in this high-risk PTSD population are warranted.

\section{Disclosures}

This work is based on research supported by the South African Research Chairs Initiative of the Department of Science and Technology and the National Research Foundation. The authors declare no conflict of interest. 


\section{References}

Acier no R, Resnick HS, Kilpatr ick DG (1997) Health impact of inter personal vi olence 1: Prevalence rates, case identif ication, and risk factors for sexual assault, physical assault, and domestic violence in men and women. Behav Med. 23:53Y63.

Adewuya AO, Afolabi MO, Ola BA, Ogundele OA, Ajibare AO, Olad ipo BF, Fakande I (2009) Post-traumatic stress disorder (PTSD) after stigma related events in HIV infected individuals in Nigeria. Soc Psychiatry Psychiatr Epidemiol. 44:761Y766.

American Psychiatric Association (Ed) (1980) Diagnostic and statistical manual of mental disorders (3rd ed). Washington, DC: American Psychiatric Association.

American Psychiatric Association (Ed) (2000) Diagnostic and statistical manual of mental disorders (4th edYtext rev). Washington, DC: American Psychiatric Association.

Becker man NL, Auerbach C (2011) PTSD and HIV in women: The role of gender in this dual diagnosis. Women Health. 51:497Y510.

Bradshaw D, Nannan N, Laubscher R, Groenewald P, Joubert J, Nojilana B, Pieterse D, Schneider M (2004) South African National Burden of Disease Study 200O: Estimates of provincial mortality. Cape Town, South Africa: Medical Research Council.

Breslau N (2002) Epidemiologic studies of trauma, posttraumatic stress disorder, and other psychiatric disorders. Can J Psychiatry. 47:923Y929.

Breslau N, Chilcoat HD, Kessler RC, Davis GC (1999a) Previous exposure to trauma and PTSD effects of subsequent trauma: Results from the Detroit Area Survey of Trauma. Am J Psychiatry. 156:902Y907.

Breslau N, Chilcoat HD, Kessler RC, Peterson EL, Lucia VC (1999b) Vulnerability to assaultive violence: Further specification of the sex difference in post-traumatic stress disorder. Psychol Med. 29:813Y821.

Brewin CR, Andrews B, Valentine JD (2000) Meta-analysis of risk factors for posttraumatic stress disorder in trauma exposed adults. $J$ Consult Clin Psychol. 68:748Y766.

Brief DJ, Bollinger AR, Vielhauer MJ (2004) Understanding the interface of HIV, trauma, post-traumatic stress disorder, and substance use and its implications for health outcomes. AIDS Care. 16:S97YS120.

Demyttenaere K, Bruffaerts R, Posada-Villa J, Gasquet I, Kovess V, Lepine JP, Angermeyer MC, Bernert S, De Girolamo G, Morosini P, Polidori G, Kikkawa T, Kawakami N, Ono Y, Takeshima T, Uda H, Karam EG, Fayyad JA, Karam AN, Mneimneh ZN, Medina-Mora ME, Borges G, Lara C, De Graaf R, Ormel J, Gureje O, Shen YC, Huang YQ, Zhang MY, Alonso J, Haro JM, Vilagut G, Bromet EJ, Gluzman S, Webb C, Kessler RC, Merikangas KR, Anthony JC, Von Korff MR, Wang PS, Brugha TS, Aguilar-Gaxiola S, Lee S, Heeringa S, Pennell BE, Zaslavsky AM, Ustun TB, Chatterji S (2004) Prevalence, severity, and unmet need for treatment of mental disorders in the World Health Organisation World Mental Health Surveys. JAMA. 291:2581Y2591.

Frans O, Rimmö PA, Aberg L, Fredrikson M (2005) Trauma exposure and posttraumatic stress disorder in the general population. Acta Psychiatr Scand. 111:291Y299.

Gray MJ, Litz BT, Hsu JL, Lombardo TW (2004) Psychometric properties of the Life Events Checklist. Assessment. 11:330Y341. 
Green BL, Goodman LA, Krupnick JL, Corcoran CB, Petty RM, Stockton P, Stern NM (2000) Outcomes of single versus multiple trauma exposure in a screening sample. J Trauma Stress. 13:271Y286.

Hapke U, Shumann A, Rumpf HJ, John U, Meyer C (2006) Post-traumatic stress disorder: The role of trauma, pre-existing psychiatric conditions, and gender. Eur Arch Psychiatry Clin Neurosci. 256:299Y306.

Hosmer D, Lemeshow S (1989) Applied logistic regression.New York: Wiley \&Sons.

Israelski, DM, Prentiss DE, Lubega S, Balmas G, Garcia P, Muhammad M, Cummings S, Koopman C (2007) Psychiatric co-morbidity in vulnerable populations receiving primary for HIV/AIDS. AIDS Care. 19:220Y225.

Kaminer DB, Grimsrud A, Myer L, Stein DJ, Williams DR (2008) Risk for post-traumatic stress disorder associated with different forms of interpersonal violence in South Africa. Soc Sci Med. 67:1589Y1595.

Kelly B, Raphael B, Judd FK, Kernutt G, Burnett P, Burrows G (1998) Posttraumatic stress disorder in response to HIV infection. Gen Hosp Psychiatry. 20:345Y352.

Kessler RC, Sonnega A, Bromet E, Hughes M, Nelson CB (1995) Posttraumatic stress disorder in the National Comorbidity Survey. Arch Gen Psychiatry. 52:1048Y1060.

Kimerling R, Calhoun KS, Forehand R, Armistead L, Morse E, Morse P, Clark R, Clark L (1999) Traumatic stress in HIV-infected women. AIDS Educ Prev. 11:321Y330.

Leserman J, Whetten K, Lowe K, Stangl D, Swartz MS, Thielman NM (2005) How trauma, recent stressful events, and PTSD affect functional health status

and health utilization in HIV-infected patients in the south. Psychosom Med. 67:500Y507.

Martin L, Kagee A (2011) Lifetime and HIV-related PTSD among persons recently diagnosed with HIV. AIDS Behav.15:125Y131.

Mar tinez A, Israelski D, Walker C, Koopman C (2002) Post-traumat ic stress dis order in women attending human imm unodef iciency vir us outpatient clinics. AIDS Patient Care STDS. 16:283Y291.

Myer L, Smit J, Le Roux L, Parker S, Stein DJ, Seedat S (2008) Common mental health disorders among HIV-infected individuals in South Africa: Prevalence, predictors, and validation of brief psychiatric rating scales. AIDS Patient Care STDS. 22:147Y158.

Myers J, Naledi T (Eds) (2008) Western Cape Burden of Disease Reduction Project: Final Report 2007 Overview and Executive Summaries. Vol 1. Cape Town, South Africa: Western Cape Department of Health. Available at: http:// www.capegateway.gov.za/eng/ pubs/reports_research/W/157844.

Nor man R, Matzopoul os R, Groenewald P, Brad shaw D (2007) The high burden of injuries in South Africa. Bull World Health Organ. 85:695Y702.

Olley BO, Gxam za F, Seedat S, Theron H, Taljaar d J, Reid E, Reuter H, Stein DJ (2003). Psychopathology and coping diagno sed HIV/AIDS patientsVThe role of gender. $S$ Afr Med 931.

Olley BO, Seedat S, Stein DJ (2006) Persistence of psychiatric disorders in a cohort of HIV/AIDS patients in South Africa: A 6-month follow-up study. JPsychosom Res.61: $479 \mathrm{Y} 484$.

Olley BO, Zei er MD, Seedat S, Stein DJ (2005) Post-traumatic stress disorder among recently diagnosed pati ents with HIV/AI DS in South Africa. AIDS Care. 17:550Y557. 
Pingo J, Seedat S (2009) The managem ent of trauma and postt raumatic stress dis order in HIV-infected individuals. S Afr J HIV Med. 10:14Y19.

Radcliffe J, Fleisher CL, Hawkins LA, Tanney M, Kassam-Adams N, Ambr ose C, Rudy BJ (2007) Posttraumatic stress and trauma histo r y in adolescents and young adults with HIV. AIDS Patient Care STDS. 21:501Y508.

Safren SA, Gershuny BS, Hendriksen E (2003) Symptoms of posttraumati c stress and death anxiety in persons with HIV and medication adherenc e diff icultie s. AIDS Patient Care STDS. 17:657Y664.

Seedat M, Van Niekerk A, Jewkes R, Suffla S, Ratele K (2009) Violence and injuries in South Africa: Prioritising an agenda for prevention. Lancet. 374:1011Y1022.

Sheehan DV, Lecrubier Y, Sheehan KH, Amorim P, Janavs J, Weiller E, Hergueta T, Baker R, Dunbar GC (1998) The Mini-International Neuropsychiatric Interview (M.I.N.I): The development and validation of a structured and diagnostic psychiatric interview for DSM-IV and ICD-10. J Clin Psychiatry. 59:22Y33.

Voges MA, Romney DM (2003) Risk and resiliency factors in posttraumatic stress disorder. Ann Gen Hosp Psychiatry. 2:4. 